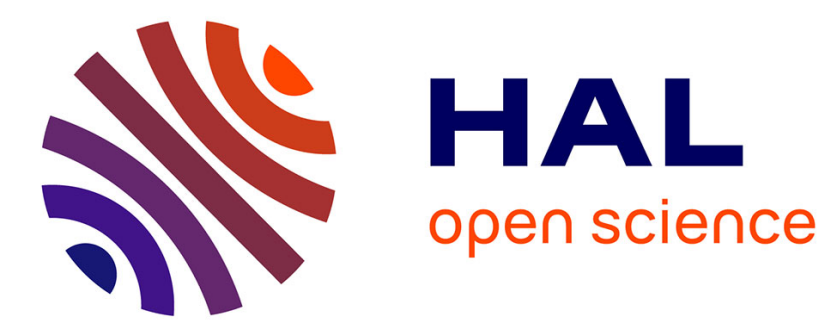

\title{
Physical controls and depth of emplacement of igneous bodies: A review
}

\author{
Thierry Menand
}

\section{To cite this version:}

Thierry Menand. Physical controls and depth of emplacement of igneous bodies: A review. Tectonophysics, 2011, 500, pp.11-19. 10.1016/j.tecto.2009.10.016 . hal-00682291

\section{HAL Id: hal-00682291 \\ https://hal.science/hal-00682291}

Submitted on 28 Apr 2015

HAL is a multi-disciplinary open access archive for the deposit and dissemination of scientific research documents, whether they are published or not. The documents may come from teaching and research institutions in France or abroad, or from public or private research centers.
L'archive ouverte pluridisciplinaire HAL, est destinée au dépôt et à la diffusion de documents scientifiques de niveau recherche, publiés ou non, émanant des établissements d'enseignement et de recherche français ou étrangers, des laboratoires publics ou privés. 


\title{
Physical controls and depth of emplacement of igneous bodies: A review
}

\author{
Thierry Menand \\ Department of Earth Sciences, Centre for Environmental and Geophysical Flows, \\ University of Bristol, Wills Memorial Building, Queen's Road, Bristol BS8 1RJ, UK
}

\begin{abstract}
The formation and growth of magma bodies are now recognised as involving the amalgamation of successive, discrete pulses such as sills. Sills would thus represent the building blocks of larger plutons (sensu lato). Mechanical and thermal considerations on the incremental development of these plutons raise the issue of the crustal levels at which magma can stall and accumulate as sills. Reviewing the mechanisms that could a priori explain sill formation, it is shown that principal physical controls include: rigidity contrast, where sills form at the interface between soft strata overlaid by comparatively stiffer strata; rheology anisotropy, where sills form within the weakest ductile zones; and rotation of deviatoric stress, where sills form when the minimum compressive stress becomes vertical. Comparatively, the concept of neutral buoyancy is unlikely to play a leading control in the emplacement of sills, although it could assist their formation. These different controls on sill formation, however, do not necessarily operate on the same length scale. The length scale associated with the presence of interfaces separating upper stiffer layers from lower softer ones determines the depth at which rigiditycontrolled sills will form. On another hand, the emplacement depths for
\end{abstract}


rheology-controlled sills is likely to be determined by the distribution of the weakest ductile zones. Whereas the emplacement depth of stress-controlled sills is determined by a balance between the horizontal maximum compressive stress, which favours sill formation, and the buoyancy of their feeder dykes, which drives magma vertically. Ultimately, the depth at which a sill forms depends on whether crustal anisotropy or stress rotation is the dominant control, i.e. which of these processes operates at the smallest length scale. Using dimensional analysis, it is shown that sill formation controlled by remote stress rotation would occur on length scales of hundreds of meters or greater. This therefore suggests that crustal heterogeneities and their associated anisotropy are likely to play a larger role than remote stress rotation in controlling sill emplacement, unless these heterogeneities are several hundred meters or more apart. This also reinforces the role of local stress barriers, owing to interactions between deviatoric stress and crustal heterogeneities, in the formation of sills.

Key words: sills, laccoliths, plutons, emplacement, magma pulses

\section{The formation of plutons}

The formation and growth of igneous bodies (plutons sensu lato) have long been recognised as important processes that have shaped much of the Earth's crust. Over the years, a growing body of geological evidence, conceptual reasoning and theoretical models has lead to a better understanding of pluton construction. When plutons, especially those of granitic nature, were before envisaged as growing by an overall inflation, their construction is now recognised as involving the accretion of repeated, discrete magma injections 
or pulses. Yet, these processes and how they operate in governing the emplacement and growth of plutons, both in space and time, are still debated (Paterson et al., 2009, this issue).

\subsection{Mechanical challenge or "the space problem"}

The formation of plutons is first a mechanical challenge. Plutons are large igneous bodies up to several kilometres to tens of kilometres in thickness. Their formation and the associated deformation of the host rocks must be mechanically compatible on the long term with the average lithospheric strain rate (Petford et al., 2000), and the depth of emplacement of these bodies does certainly play a significant role. Indeed, the emplacement of a pluton in the shallow upper crust will be facilitated by the presence of the near free surface, whereas the deformation induced by the emplacement of deeper plutons in the lowermost parts of the crust will benefit from ductile flow, either from the mantle or the ductile crust or even both (Petraske et al., 1978; Cruden, 1998; Cruden and McCaffrey, 2001). However, the development of igneous bodies may not follow a single growth process. Extensive field measurements of the geometry and dimensions of many intrusions, from the smaller sills to the larger batholiths, seem to indicate that a generic, continuous link exists between the thickness and the average horizontal dimension of these intrusions, but also that this scaling relationship does not seem to follow a single power law (McCaffrey and Cruden, 2002; Cruden and McCaffrey, 2006). Instead, sills seem to grow mainly by lateral propagation whereas laccoliths seem to grow by vertical thickening before extending laterally again as plutons and batholiths, hence suggesting different growth mechanisms depending on the size of the intrusive body that is considered (Pollard and 
Johnson, 1973; Cruden and McCaffrey, 2002).

\subsection{Thermal considerations}

The construction and development of an active magma chamber is also a thermal problem. For a magma chamber to remain active or for an igneous body to be able to convect, heat must be accumulated in that body at rates that are higher than that at which heat is conducted away from the body. Recent studies have shown that the thermal evolution of an igneous body depends critically on several parameters including the supply rate of magma that feeds that body as well as the position of this igneous body along the ambient geotherm. Indeed, the depth at which magma is accumulated, or stored, in the crust is important because this determines the initial temperature of the igneous body and thus its subsequent thermal evolution (Annen et al., 2006; Michaut and Jaupart, 2006; Annen, 2009a).

The mechanical and thermal aspects of pluton formation and growth are also intimately intertwined. The mechanics and associated styles of pluton formation directly affect the geometry of a pluton, which in turn controls its thermal evolution. This has strong implications for magma differentiation and anatexis. Plutons can grow through different emplacement sequences. Repeated amalgamation of magma of younger age underneath older igneous material would lead to grow by under-accretion (Harrison et al., 1999; de Saint-Blanquat et al., 2001; Michel et al., 2008). The opposite growth sequence, referred to as over-accretion, occurs when younger igneous units accumulate on top of older ones (Wiebe and Collins, 1998; Benn et al., 1999; Galerne et al., 2008). Finally, pluton formation can also involved scattered injections of magma, with septa of host rocks trapped in between individ- 
ual intrusions (Quick et al., 1994; Westerman et al., 2004). These different growth sequences will lead to radically different thermal evolutions, and thus to extremely different relative amounts of residual melt from incomplete crystallization of the pulses and of partial crustal melt (Annen et al., 2008; Annen, 2009b, this issue).

\subsection{Evidences for sills as pluton-building blocks}

There is a vast body of evidence from geological, geophysical and geochronological data (Cargill et al., 1928; Hawkes and Hawkes, 1933; Gretener, 1969; Bedard et al., 1988; John, 1988; Gudmundsson, 1990; Hutton, 1992; John and Blundy, 1993; Rutter et al., 1993; Vigneresse and Bouchez, 1997; Wiebe and Collins, 1998; Benn et al., 1999; Coleman et al., 2004; Glazner et al., 2004; Horsman et al., 2005; Morgan et al., 2005; Belcher and Kisters, 2006; de Saint-Blanquat et al., 2006; Pasquarè and Tibaldi, 2007; Horsman et al., 2009; Morgan et al., 2008; Miller et al., 2009, this issue) as well as theoretical models (Gudmundsson, 1990; Annen and Sparks, 2002; Michaut and Jaupart, 2006; Menand, 2008) that plutons (sensu lato) throughout the crust grow by the amalgamation of individual intrusive igneous sheets. Although rare instances of plutons that grew by amalgamation of vertical dykes have been identified (Allibon et al., 2009, this issue), the individual sheets making up most plutons can be described as sills. Sills could therefore be envisaged as representing the building blocks of larger bodies (Horsman et al., 2005; Morgan et al., 2005; de Saint-Blanquat et al., 2006; Menand, 2008; Horsman et al., 2009; Morgan et al., 2008; Miller et al., 2009, this issue). This in turn raises the questions of the formation of sills, their emplacement depth, and how this depth is determined. 


\section{Existing models of sill formation}

A sill forms when a dyke stops it vertical propagation and then intrudes along an existing discontinuity (Fig. 1). Several models have been proposed for the arrest of dykes and associated sill formations.

\subsection{Buoyancy control}

Neutral buoyancy has long been proposed as a mechanism to form sills, with sills emplacing at crustal levels where their magma becomes neutrally buoyant (Gilbert, 1877; Corry, 1988). However, this model contradicts field observations (e.g. the Buckhorn Ridge intrusion in Utah, Johnson and Pollard, 1973) and 3D seismic data (Thomson and Hutton, 2004; Cartwright and Hansen, 2006; Thomson, 2007) of sills intruding different rock strata, and thus characterised by different density, and of transgressive sills intruding successively different stratigraphic levels; if one of those levels represents a level of neutral buoyancy the others clearly cannot. Likewise, if neutral buoyancy were to control the formation of sills and therefore the arrest of dykes then it would almost invariably prevent basaltic lava flows to occur on the Earth's surface owing to their larger density.

Thus, alone, a level of neutral buoyancy is unlikely to be sufficient for promoting sill formation. Although in some cases it could indeed arrest the vertical propagation of a dyke (Pinel and Jaupart, 2004), further magma

flow would most likely result in lateral dyke propagation, as illustrated by the laboratory experiments of Lister and Kerr (1991), rather than sill formation because this would also requires a rotation of the intrusion so that it propagates in a horizontal plane. However, Taisne and Jaupart (2009) 
have recently shown that buoyancy effect may lead to sill formation in specific conditions. Buoyancy-driven dyke propagation is determined by a local buoyancy balance in the inflated nose region of the dike, independently of the total buoyancy of the magma column between source and tip (Lister and Kerr, 1991; Taisne and Jaupart, 2009). Therefore, a dyke intruding low-density layers would develop an internal overpressure that may be large enough to generate a horizontally propagating sill at or near the base of the

low-density layers. However, the development of such a large overpressure requires the thickness of these low-density layers to be at least $700 \mathrm{~m}$ and $2 \mathrm{~km}$ on average. This is typically larger than the thickness of sedimentary strata (e.g. Hinze et al., 1978), and therefore suggests that the concept of neutral buoyancy does not provide a complete explanation for the mechanism and level of sill emplacement, although they could assist their formation. Additional mechanisms are thus required.

\subsection{Rheology control}

The observations of sills intruding soft layers such as shales, mudstones or hyaloclastites (Mudge, 1968; Fridleifsson, 1977; Antonellini and Cambray, 1992), which might have deformed ductily at the time of sill formation, suggest that rheology contrasts between adjacent crustal layers can play an important role in controlling sill formation.

Parsons et al. (1992) suggest that the rheology contrast between ductile rock layers and adjacent elastic, brittle strata would help stop feeder dykes and promote sill formation. Their reasoning is that a vertical dike increases locally the horizontal least principal stress of the host rocks it intrudes. This effect would be magnified in rheologically ductile zones owing to partial re- 
laxation of pre-existing deviatoric stress. Therefore, a dyke or a series of dyking events within ductile rocks could modify the stress conditions to the extent that the local least principal stress becomes vertical, which would thus force subsequent magma intrusions within this ductile region to form sills.

Ductile behaviour is also expected from partially solidified, or heated, successive magma pulses, as they accumulate in the same region. In this case, the emplacement of sills could be controlled by the presence of horizons separating crystal-poor from crystal-rich material with sills forming within the weakest ductile zones (Wiebe and Collins, 1998; Miller et al., 2009, this issue).

\subsection{Rigidity anisotropy}

However, in many and perhaps most cases, sills form within rocks that deform elastically instead of ductily. One possibility is that sills form because of a favourable crustal rigidity anisotropy. Many field studies show that when sills intrude sedimentary sequences they commonly abut stiff rock layers, thus suggesting that these rigid layers could have arrested the vertical propagation of the feeder dyke and encouraged sill formation. Examples include high rigidity sandstones, limestones, ancient lava flows and solid mushes of highcrystal content (Fridleifsson, 1977; Hyndman and Alt, 1987; Gudmundsson and Brenner, 2001; Holness and Humphreys, 2003; Miller et al., 2009, this issue).

Using analogue experiments with gelatine solids, Kavanagh et al. (2006) have tested this hypothesis. Their experiments show that under lithostatic conditions the formation of sills requires the presence of interfaces. However, the presence of an interface is not sufficient. The experiments show that sills 
could only form when their feeder encountered an interface that separates a rigid layer that overlies a less rigid, lower layer (Fig. 2). In the opposite case, where a less rigid layer lies on top of a more rigid one, feeders would not intrude the interface between the two layers but would instead cross-cut that interface and carry on their propagation as vertical dykes (Kavanagh et al., 2006).

Additionally, the properties of the interface itself can also have an important effect on whether a dyke would be deflected and intrude the interface. Theoretical analysis shows that whether an interface is intruded or crossed over depends on the elastic properties of the adjacent layers as well as the interface toughness relative to that of the upper layer, with stiffer upper layers favouring intrusion of the interface (He and Hutchinson, 1989; Gudmundsson, 2009, this issue). This analysis is supported by the analogue experiments of Kavanagh et al. (2006), who report instances where a dyke was expected to form a sill, because a rigid layer was overlying a less rigid layer, but instead was arrested by the interface without intruding the interface nor penetrating the upper layer; the interface was inferred to be too strong to be intruded by the dyke. Also, in the case of weak and shallow contacts, sill intrusion of these contacts could also occur by debounding whereby as a dyke approaches a weak contact, the tensile stress generated at the dyke tip is large enough to open up this contact and intrude it as a sill (the Cook-Gordon mechanism referred to by Gudmundsson, 2009, this issue).

\subsection{Stress control}

Sill formation can also result from adequate stress conditions. Igneous intrusions tend to propagate perpendicular to the least compressive stress 
(Anderson, 1951). Therefore, dykes are expected to form when the least compressive stress is horizontal, whereas sills should form when the least compressive stress is vertical. A corollary is that a transition from dyke to sill is expected when the minimum compressive stress rotates from being horizontal, such as in extension tectonic environment, to being vertical, which would be the case in a horizontally compressive stress field.

However, the orientation of an intrusion does not solely depend on the principal stress directions. It depends also on the magma overpressure, in that intrusions with higher overpressure need to propagate over greater distance before they can fully adjust their propagation to the principal directions (Mériaux and Lister, 2002). This is confirmed by recent analogue experiments which investigated the transition from dyke to sill as a result of a rotation of the deviatoric stresses (Menand et al., 2009). In these experiments, air was injected into a solid of gelatine that was then compressed laterally so that the minimum deviatoric compressive stress became vertical. Air acted as an analogue for buoyant magma, and the solid gelatine was used as an analogue for elastic crustal rocks. Air-filled cracks initially driven vertically by their buoyancy change their direction of propagation and ultimately form sills in response to the minimum compressive stress being vertical (Fig. 3). But this trajectory re-adjustment is not instantaneous. Cracks of higher buoyancy require greater distances to re-orient themselves fully, and they could reach the surface in spite of the vertical minimum compressive stress, and therefore not form sills, if these distances happen to be larger than that separating the intrusions from the surface (Menand et al., 2009).

Stress conditions favourable to sill formation can also result from the 
presence of layered elastic rocks. A multilayer subjected to horizontal compression, for instance, would result in the stiffest layers taking up most of the compressive stress, whereas if this multilayer were in horizontal extension, the softest layers would experience lower reduction in compressive stress and thus appear comparatively more compressive (Gudmundsson, 1986, 1990). Those layers where the minimum compressive stress becomes vertical would thus represent favourable horizons for sill intrusions.

\section{Depth of emplacement: what are the controls?}

Sills are expected to form in the crust owing to either favourable contrasts in mechanical or rheological properties, or favourable stress conditions. These different controls on sill formation, however, do not necessarily operate on the same length scale. In fact, the depth at which a sill forms will depend on which process is dominant, i.e. which process operates on the smallest length scale.

\subsection{Rheology-contrast control}

Field observations suggest that the formation of sills controlled by rheology contrasts and, by extension, the depth at which these sills are emplaced are likely to be determined by the distribution of the weakest ductile zones (Wiebe and Collins, 1998; Miller et al., 2009, this issue).

\subsection{Rigidity-contrast control}

The formation of sills through a rigidity-contrast control requires not only the presence of layers with different mechanical properties but also necessitates the presence of interfaces that separate more competent layers overlay- 
ing less rigid ones (Kavanagh et al., 2006; Gudmundsson, 2009, this issue). Therefore, the length scale associated with the presence of these specific interfaces is what determines the depth at which rigidity-controlled sills would form.

\subsection{Stress control}

In contrast, stress rotation can occur in homogeneous as well as heterogeneous solids. Stress rotation could occur in response to magma intrusion within an edifice (Roman et al., 2004, 2006) or owing to the load of an edifice itself (Pinel and Jaupart, 2004), for instance. Although the Earth's crust is highly heterogeneous, considering the homogeneous case is instructive because it reveals the length-scale over which the effect of the stress-control alone operates. Considering the crust as homogeneous, sills would be expected to form within the crustal regions where the minimum compressive stress has been rotated vertically. In these specific regions, Menand et al. (2009) have shown that the depth at which sills form is determined by a balance between the horizontal maximum deviatoric compressive stress, which favours the formation of sills, and magma buoyancy, which drives magma vertically and thus opposes sill formation. This competition between maximum deviatoric compressive stress and buoyancy determines the length scale over which stress-controlled sill formation occurs.

Menand et al. (2009) applied dimensional analysis to their experimental data, which enabled them to relate the vertical distance, $d$, the buoyant crack needed to propagate before turning into a sill to the buoyancy of the crack and the horizontal maximum deviatoric compressive stress, $\sigma_{x}$. Upscaled to magmatic conditions over a range of reasonable geological values - tensile 
strength of homogeneous host rock $T_{s}=1-10 \mathrm{MPa}$, density difference between dyke and host rock $\Delta \rho=100-500$, and $\sigma_{x}=0.1-100 \mathrm{MPa}-$ Menand et al. (2009) expressed the vertical distance, $d$, as

$$
d \simeq \frac{T_{s}}{\Delta \rho g} \exp \left[(0.051 \pm 005) \frac{T_{s}}{\sigma_{x}}\right]
$$

where the dimensionless constant was determined by their dimensional analysis. (The reader is referred to Menand et al. (2009) for a more detailed account of how this equation was determined.) Their results show that in a homogeneous and elastic crust, and over this range of geological conditions, a dyke would have to travel a distance of the order of at least $200 \mathrm{~m}$ and in most cases of the order of one to ten kilometres to adjust to a vertical minimum compressive stress and turn into a sill (see figure 4 in Menand et al., 2009).

This distance is typically greater than the average thickness of lithologial units, and therefore suggests that in most cases crustal heterogeneities and the distance between interfaces that are favourable to sill intrusions will play a larger role than remote tectonic stress rotation in determining where in the crust sills form, unless these favourable interfaces are several hundreds meters or more apart.

\subsection{Level of neutral buoyancy}

As discussed previously, neutral buoyancy alone is not expected to control sill formation, although it could arrest the vertical propagation of a rising buoyant dyke (Lister and Kerr, 1991; Pinel and Jaupart, 2004). However, overpressures large enough for sill intrusion could potentially develop provided high-density dykes manage to propagate far enough into low-density 
rocks (Taisne and Jaupart, 2009). Also, because a level of neutral buoyancy corresponds to the crustal level where a dyke is no longer buoyant and thus does not have any more internal vertical driving force, a dyke would become even more sensitive to horizontal compressive stress near its level of neutral buoyancy. So in principle, levels of magma neutral buoyancy could assist the formation of stress-controlled sills because, provided adequate stress conditions, levels of neutral buoyancy would represent advantageous horizons for sill emplacement.

\subsection{Implications}

In reviewing the processes that control the emplacement of sills and the length-scales over which these processes operate, it appears that crustal heterogeneities are likely to play a dominant role. Heterogeneities can directly induce sill formation through rigidity or rheology anisotropy, but they can also interact with tectonic stresses and lead to sill-favourable conditions. The presence of a level of neutral buoyancy in a horizontal compressive stress field is one example. Interplay between stress field and heterogeneous crustal layers is another. Indeed, layered elastic rocks can lead to strong stress anisotropy, even in the case of isotropic remote stress, which would thus strengthen some strata relative to others (Gudmundsson, 1986; Gudmundsson and Brenner, 2001; Menand, 2008).

Better constraints on the geometry of crustal heterogeneities, their physical and rheological properties as well as the tectonic stresses that they experience are therefore crucial in order to improve our understanding of how and where sills form in the crust. 


\section{Sill amalgamation and the formation of plutons}

\subsection{Field evidences}

Field evidences for pluton formation by sill amalgamation at mid-crustal levels or in the upper crust are numerous (e.g. John and Blundy, 1993; Horsman et al., 2005; Morgan et al., 2005; Belcher and Kisters, 2006; de SaintBlanquat et al., 2006; Pasquarè and Tibaldi, 2007; Horsman et al., 2009; Morgan et al., 2008). Although more scarce, field evidences of sills or magma pulses amalgamating to form plutons in the lower crust do also exist (Rutter et al., 1993; Quick et al., 1994). Additional, indirect evidences come from seismic studies of magma underplating that reveal an internal layering, suggestive of sills or sill-like igneous intrusions (Al-Kindi et al., 2003). It has also been proposed that underplating involving successive episodes of repeated sill injections and their subsequent cooling could generate episodes of surface uplift and subsidence, and thus explain the occurrence of rapid sea-level rises observed on very short time scales (Maclennan and Lovell, 2002).

\subsection{A mechanical model}

Recently, Menand (2008) proposed a model for the growth of igneous bodies by vertical stacking of successive sills. This generic model is applicable to bodies of moderate to intermediate size, from sills to plutons (sensu lato) and including laccoliths. It would not be appropriate to larger bodies such as batholiths, however, as they seem to develop essentially by lateral growth, which would thus require another mechanism (Cruden and McCaffrey, 2006). This model is based on the experiments of Kavanagh et al. (2006), which show that in the absence of external stresses sills form at the interfaces between 
upper, rigid layers overlaying lower, weaker layers. From these experimental observations, it follows that if a sill forms owing to a favourable rigidity contrast then once this sill has solidified it will necessarily provide another interface with favourable rigidity contrast for the emplacement of a subsequent sill. Indeed, once solidified this sill will either become more rigid than the rocks beneath itself or, alternatively, less rigid than these rocks and thus less rigid than the rocks above itself. In either case, this solidified sill will provide a favourable site for the emplacement of another sill either beneath or above itself, respectively. Therefore, this model provides a mechanism for the vertical stacking of successive sills, and thus the formation and growth of laccoliths, by under- or over-accretion, or even by mid-accretion if favourable rigidity interfaces develop between adjacent sills.

The suggestion that laccoliths can develop and grow by the vertical stacking of individual and successive sills is in agreement with unequivocal field observations made in the Henry Mountains, Utah, and in Icelan (Hawkes and Hawkes, 1933; Horsman et al., 2005; Morgan et al., 2005; de Saint-Blanquat et al., 2006; Pasquarè and Tibaldi, 2007; Horsman et al., 2009; Morgan et al., 2008; Tibaldi and Pasquarè, 2008). Moreover, it has also been proposed that laccoliths of different sizes could represent the various stages of pluton formation as one moves in time from sills to laccolith to larger pluton (Morgan et al., 2005; Horsman et al., 2009), as illustrated in Fig. 4.

\subsection{Implications}

This mechanical model implies that laccolith formation does not necessarily requires a single episode of magma injection, with laccolith only forming by inflation of a single sill when it is able to lift up the overlying strata (Pol- 
lard and Johnson, 1973; Pollard and Holzhausen, 1979; Fialko et al., 2001). The complementary view is that laccoliths can also develop out of multiple, vertically-stacked pulses (Horsman et al., 2009). The model could thus explain the formation of internally-layered laccoliths (Tibaldi and Pasquarè, 2008) and plutons (Benn et al., 1999; Miller et al., 2009, this issue), as well as Christmas-tree laccoliths (Westerman et al., 2004).

This model has also implications for the length scale of large igneous bodies. The lateral size of plutons growing by amalgamation of successive pulses or sills would essentially be of the same order of the length of the pulses that compose them. The pluton thickness, on the contrary, would be the cumulative thickness of all these pulses. This is in accord with field observations (Horsman et al., 2005; de Saint-Blanquat et al., 2006; Horsman et al., 2009; Morgan et al., 2008), and would also explain why and how laccoliths, and to a lesser extend larger plutons $(\sim 10-100 \mathrm{~km}$ of lateral extend), tend to grow mainly by vertical expansion with comparatively little lateral propagation (Cruden and McCaffrey, 2006).

Another inference is that the time scale for the growth of laccoliths and larger plutons is much larger than the time scale associated with the successive magma injections. In fact, the time scale of pluton growth would mainly be the cumulative time that separates the individual pulses since, comparatively, the time for their emplacement is instantaneous (Cruden and McCaffrey, 2001). Therefore, in accord with field and geochronological data, larger plutons develop over much longer periods of time than smaller laccoliths and sills(de Saint-Blanquat et al., 2009). That the average rate of pluton construction is much smaller than the flux of individual magma injections is 
an important consideration for the thermal evolution of plutons (e.g. Annen, 2009b, this issue).

\section{Discussion and challenges}

Our understanding of pluton construction has improved, leading to a better perception of how igneous bodies intrude into the crust. Pluton formation is now recognised as being an incremental, discontinuous process. This leads to new challenges for the interpretation of field observations, as well as fundamental questions about the mechanics of pluton emplacement and assembly that need to be fully addressed.

\subsection{Geometry and structure of plutons}

Incremental growth of plutons by amalgamation of repeated small magma pulses is mechanically more viable than plutons growing by emplacement of larger magma volumes, and thus alleviates the space problem associated with pluton growth by overall inflation (e.g. Petford et al., 2000). Also, the growth of laccoliths by incremental stacking of igneous sheets enable to explain why and how their geometry depart from that of individual sills (Cruden and McCaffrey, 2006).

However, this also leads to new challenges when interpreting field observations and relating them to the processes involved during pluton construction. The relationship between tectonics and pluton emplacement, and their possible interactions, remain to be clarified (see for instance Allibon et al., 2009, this issue; de Saint-Blanquat et al., 2009, this issue; and Vigneresse, 2009, this issue). Another illustration is the recent and controversial view that 
stoping might not be a volumetrically significant process during pluton emplacement (Glazner and Bartley, 2008a; Clarke and Erdmann, 2008; Glazner and Bartley, 2008b; Paterson et al., 2008; Yoshinobu and Barnes, 2008). New challenges arise when interpreting field observations because plutons growth is a discontinuous process. It involves a succession of processes, both in space and time, that do not necessarily operate at the same length- and time-scales. With time, and depending on the amount of magma that is emplaced and on the manner in which the host rocks accommodate this emplacement, these processes tend to overprint each other and become increasingly more cryptic as pluton volume increases (Glazner et al., 2004; Horsman et al., 2009; Miller et al., 2009, this issue).

\subsection{Rate of growth and igneous petrogenesis}

Incrementally growing plutons reconcile the apparent contradicting requisites of rapid magma emplacement, to prevent its freezing on its way from source region to emplacement level, and overall formation over large periods of time (Petford et al., 2000; Glazner et al., 2004). This has also implications for the thermal evolution and differentiation of magmas. Indeed, the incremental injection of magma in a crustal region leads to a thermal evolution of that system that is fundamentally different from that associated with the emplacement of a single larger volume of magma, not only because magma, hence heat, is injected incrementally through time but also because of the way the pluton will evolve and grow, e.g. under- versus over-accretion (Annen et al., 2008; Annen, 2009b, this issue), and also because of potential kinetics effects that could take place in the thinnest increments (Michaut and Jaupart, 2006, 2009, this issue). 
There are also important implications for the relationship between plutonism and volcanism. Developing and maintaining a magma chamber active requires a delicate balance between the rate at which heat is accumulated within a region of the crust and that at which it is conducted away, so that a significant portion of the magmatic body could be eruptible (Gudmundsson, 1990). In fact, recent numerical simulations show that active magma chambers can only develop over a rather limited range of emplacement rates (Annen, 2009a); lower rates would prevent magma chambers to develop whereas higher rates would lead to eruption and drainage of the magma chamber, which would then accelerate its cooling and solidification. This would be especially true for developing the large magma chambers needed to feed supereruptions. Moreover, these results suggest that the growth of plutons would be a multi-timescale process with large magma chambers developing during episodes of highest magma flux, and that these transient magma chambers would only represent small portions of the pluton final volume (Annen, 2009a). This in turn raises the issue of the magma fluxes associated with the construction of plutons (de Saint-Blanquat et al., 2009, this issue), and more specifically how these fluxes can be determined with enough accuracy over the various time-scales of pluton growth (Paterson et al., 2009, this issue).

\subsection{What is the impact on the local stress field?}

One consequence of incremental pluton growth is that the local stress field is likely to change over time as subsequent pulses are assembled together. Although not yet fully quantified, this is likely to have an impact on the emplacement of subsequent pulses, with potentially the exchange of principal stresses (Vigneresse, 2009, this issue), and thus on the overall geometry of 
the pluton as it grows. Therefore, further studies need to concentrate on how the local stress field evolves during pluton growth and how this impacts on pluton development.

\subsection{How does pluton growth affect the rheology of both host rocks and mag- mas?}

Another and related issue that further studies need to address is that of the rheology of both the host rocks and the magma. As plutons form, heat accumulates within an increasingly larger crustal zone. How heat accumulates over time dictates the thermal evolution of magmas (Michaut and Jaupart, 2006; Annen et al., 2008). Therefore, this will also affect their rheology, how much magma solidifies and remains solid within a pluton or instead becomes fluid or forms a mush. This has strong implications on the manner with which successive pulses will amalgamate and thus on potential magma mixing or mingling (Miller et al., 2009, this issue).

As magma and heat are stored in a crustal region, the rheological properties of the host rock will also evolve. These rheological properties control how host rocks accommodate the deformation induced by pluton growth, and this response is coupled with the temperature of the rocks; cold rocks can not sustain high emplacement rates without fracturing and thus promoting eruptions, whereas hotter rocks would instead behave in a more viscous manner and thus accommodate the associated deformation (Jellinek and DePaolo, 2003). Furthermore, the response of rocks will depend on the volume of the pluton, or the magma chamber, and therefore on how it grows over time because a given magma emplacement rate will induce comparatively lower deformation for a larger pluton (Jellinek and DePaolo, 2003). What 
remains difficult to assess, however, is how the rheological behaviour of the host rocks evolves during pluton growth, from initially being essentially elastic to gradually becoming more viscous, and how this affects the subsequent amalgamation of magma pulses (Marko and Yoshinobu, 2009, this issue).

\section{Acknowledgements}

I thank Michel de Saint-Blanquat and Eric Horsman for discussing at length the geology and formation of the Henry Mountains intrusions. I also acknowledge Michel de Saint-Blanquat for kindly providing figure 1 and Eric Horsman for providing the graphic material used in figure 4 of the present paper. This paper was greatly improved thanks to the constructive reviews of Michel de Saint Blanquat, Agust Gudmundsson and Olivier Merle. This research was supported by a Leverhulme Trust research grant. Additional funding from the CNRS-INSU-3F PULSE 2008 grant is also acknowledged.

\section{References}

Al-Kindi, S., N. White, M. Sinha, R. England, and R. Tiley (2003). Crustal trace of a hot convective sheet. Geology 31, 207-210.

Allibon, J., F. Bussy, E. Léwin, and B. Darbellay (2009, this issue). The tectonically controlled emplacement of a vertically sheeted gabbro-pyroxenite intrusion: feeder-zone of an ocean-island volcano (Fuerteventura, Canary Islands). Tectonophysics.

Anderson, E. M. (1951). The Dynamics of Faulting and Dyke Formation with Applications to Britain (Second Edition). Oliver and Boyd Ltd., Edinburgh and London. 
Annen, C. (2009a). From plutons to magma chambers: Thermal constraints on the accumulation of eruptible silicic magma in the upper crust. Earth and Planetary Science Letters 284 (3-4), 409-416.

Annen, C. (2009b, this issue). Implications of incremental emplacement of magma bodies for magma differentiation, thermal aureole dimensions and plutonism-volcanism relationships. Tectonophysics, 1-8.

Annen, C., J. D. Blundy, and R. S. J. Sparks (2006). The genesis of intermediate and silicic magmas in deep crustal hot zones. J. Petrol. 47, 505-539.

Annen, C., J. D. Blundy, and R. S. J. Sparks (2008). The sources of granitic melt in deep hot zones. Trans. R. Soc. Edinburgh: Earth Sci. 97, 297-309.

Annen, C. and R. S. J. Sparks (2002). Effects of repetitive emplacement of basaltic intrusions on thermal evolution and melt generation in the crust. Earth Planet. Sci. Lett. 203, 937-955.

Antonellini, M. A. and F. W. Cambray (1992). Relations between sill intrusions and bedding-parallel extensional shear zones in the Mid-continent Rift System of the Lake Superior region. Tectonophysics 202, 331-349.

Bedard, J. H., R. S. J. Sparks, M. Renner, M. J. Cheadle, and M. A. Hallworth (1988). Peridotite sills and metasomatic gabbros in the Eastern Layered Series of the Rhum complex. J. Geol. 145, 207-224.

Belcher, R. W. and A. F. M. Kisters (2006). Progressive adjustments of ascent and emplacement controls during incremental construction of the 3.1 Ga Heerenveen batholith, South Africa. J. Struc. Geol. 28, 1406-1421. 
Benn, K., W. Roest, P. Rochette, N. Evans, and G. Pignotta (1999). Geophysical and structural signatures of syntectonic batholith construction: the south mountain batholith, meguma terrane, nova scotia. Geophys. J. Int. $136(1), 144-158$.

Cargill, H., L. Hawkes, and J. Ledeboer (1928). The major intrusions of south-eastern iceland. Quarterly Journal of the Geological Society 84(14), 505-539.

Cartwright, J. and D. M. Hansen (2006). Magma transport through the crust via interconnected sill complexes. Geology 34, 929-932.

Clarke, D. B. and S. Erdmann (2008). Is stoping a volumetrically signifi cant pluton emplacement process?: Comment. Geol. Soc. Am. Bull. 120, 1072-1074.

Coleman, D. S., W. Gray, and A. F. Glazner (2004). Rethinking the emplacement and evolution of zoned plutons: geochronologic evidence for incremental assembly of the Tuolumne Intrusive Suite, California. Geology 32, 433-436.

Corry, C. E. (1988). Laccoliths: mechanics of emplacement and growth. Geol. Soc. Am. Spec. Pap. 220.

Cruden, A. R. (1998). On the emplacement of tabular granites. J. Geol. Soc. London 155, 853-862.

Cruden, A. R. and K. J. W. McCaffrey (2001). Growth of plutons by floor subsidence: Implications for rates of emplacement, intrusion spacing and melt-extraction mechanisms. Phys. Chem. Earth (A) 26, 303-315. 
Cruden, A. R. and K. J. W. McCaffrey (2002). Different scaling laws for sills, laccoliths and plutons: Mechanical thresholds on roof lifting and floor depression. In C. Breitkreuz, A. Mock, and N. Petford (Eds.), First International Workshop: Physical Geology of Subvolcanic Systems - Laccoliths, Sills, and Dykes (LASI), Volume 20 of Wissenschaftliche Mitteilungen des Institutes für Geologie der TU Bergakademie Freiberg, pp. 15-17.

Cruden, A. R. and K. J. W. McCaffrey (2006). Dimensional scaling relationships of tabular igneous intrusions and their implications for a size, depth and compositionally dependent spectrum of emplacement processes in the crust. EOS Trans. AGU 87(52). Fall Meet. Suppl., Abstract V12B-06.

de Saint-Blanquat, M., G. Habert, E. Horsman, R. D. Law, O. Vanderaeghe, S. Morgan, and B. Tikoff (2009, this issue). Multiscale magmatic cyclicity, duration of pluton construction, and the paradoxical relationship between tectonism and plutonism in continental arcs. Tectonophysics.

de Saint-Blanquat, M., G. Habert, E. Horsman, S. S. Morgan, B. Tikoff, P. Launeau, and G. Gleizes (2006). Mechanisms and duration of nontectonically assisted magma emplacement in the upper crust: The Black Mesa pluton, Henry Mountains, Utah. Tectonophysics 48, 1-31.

de Saint-Blanquat, M., R. Law, J. Bouchez, and S. Morgan (2001). Internal structure and emplacement of the papoose flat pluton: An integrated structural, petrographic, and magnetic susceptibility study. Bulletin of the Geological Society of America 113(8), 976-995.

Fialko, Y. A., Y. Khazan, and M. Simons (2001). Deformation due to a pres- 
surized horizontal circular crack in an elastic half-space, with application to volcano geodesy. Geophys. Int. J. 146, 181-190.

Fridleifsson, I. B. (1977). Distribution of large basaltic intrusions in the Icelandic crust and the nature of the layer 2-layer 3 boundary. Geol. Soc. Am. Bull. 88, 1689-1693.

Galerne, C. Y., E.-R. Neumann, and S. Planke (2008). Emplacement mechanisms of sill complexes: Information from the geochemical architecture of the golden valley sill complex, south africa. Journal of Volcanology and Geothermal Research 177(2), 425-440.

Gilbert, G. K. (1877). Geology of the Henry Mountains, Utah. U.S. Geographical and Geological Survey of the Rocky Mountain Region.

Glazner, A. F. and J. M. Bartley (2008a). Is stoping a volumetrically signifi cant pluton emplacement process? Geol. Soc. Am. Bull. 118, 1185-1195.

Glazner, A. F. and J. M. Bartley (2008b). Reply to comments on "Is stoping a volumetrically significant pluton emplacement process?". Geol. Soc. Am. Bull. 120, 1082-1087.

Glazner, A. F., J. M. Bartley, D. S. Coleman, W. Gray, and R. Z. Taylor (2004). Are plutons assembled over millions of years by amalgamation from small magma chambers? GSA Today 14, 4-11.

Gretener, P. E. (1969). On the mechanics of the intrusion of sills. Can. J. Earth Sci. 6, 1415-1419. 
Gudmundsson, A. (1986). Formation of crustal magma chambers in Iceland. Geology 14, 164-166.

Gudmundsson, A. (1990). Emplacement of dikes, sills and crustal magma chambers at divergent plate boundaries. Tectonophysics 176, 257-275.

Gudmundsson, A. (2009, this issue). Deflection of dykes into sills at discontinuities and magma-chamber formation. Tectonophysics.

Gudmundsson, A. and S. L. Brenner (2001). How hydrofractures become arrested. Terra Nova 13, 456-462.

Harrison, M., M. Grove, K. Mckeegan, C. Coath, O. Lovera, and P. Fort (1999). Origin and episodic emplacement of the manaslu intrusive complex, central himalaya. Journal of Petrology 40(1), 3-19.

Hawkes, L. and H. K. Hawkes (1933). The Sandfell laccolith and "dome of elevation". Quart. J. Geol. Sot. London 89, 379-400.

He, M. Y. and J. W. Hutchinson (1989). Crack deflection at an interface between dissimilar elastic materials. International Journal of Solids and Structures 25(9), 1053-1067.

Hinze, W., J. Bradley, and A. Brown (1978). Gravimeter survey in the michigan basin deep borehole. Journal of Geophysical Research 83(B12), $5864-5868$.

Holness, M. B. and M. C. S. Humphreys (2003). The Traigh Bhàn na Sgùrra sill, Isle of Mull: Flow localization in a major magma conduit. J. Petrol. 44, $1961-1976$. 
Horsman, E., S. Morgan, M. de Saint-Blanquat, G. Habert, R. Hunter, A. Nugent, and B. Tikoff (2009). Emplacement and assembly of shallow intrusions from multiple magma pulses, Henry Mountains, Utah. In A. F. e. a. Kisters (Ed.), Sixth Hutton Symposium on the Origin of Granite and Related Rocks, Special Volume of the Transactions of the Royal Society of Edinburgh. in press.

Horsman, E., B. Tikoff, and S. Morgan (2005). Emplacement-related fabric and multiple sheets in the Maiden Creek sill, Henry Mountains, Utah, USA. J. Struc. Geol. 27, 1426-1444.

Hutton, D. H. W. (1992). Granite sheeted complexes: evidence for the dyking ascent mechanism. Trans. R. Soc. Edinburgh: Earth Sci. 83, 377-382.

Hyndman, D. W. and D. Alt (1987). Radial dikes, laccoliths and gelatin models. J. Geol. 95, 763-774.

Jellinek, A. M. and D. J. DePaolo (2003). A model for the origin of large silicic magma chambers: precursors of caldera-forming eruptions. Bull. Volcanol. 65, 363-381.

John, B. E. (1988). Structural reconstruction and zonation of a tilted midcrustal magma chamber: The felsic Chemehuevi Mountains plutonic suite. Geology 16, 613-617.

John, B. E. and J. D. Blundy (1993). Emplacement-related deformation of granitoid magmas, southern Adamello Massif, Italy. Geol. Soc. Am. Bull. 105, 1517-1541. 
Johnson, A. M. and D. D. Pollard (1973). Mechanics of growth of some laccolithic intrusions in the Henry Mountains, Utah, I. Field observations, Gilbert's model, physical properties and flow of the magma. Tectonophysics 18, 261-309.

Kavanagh, J. L., T. Menand, and R. S. J. Sparks (2006). An experimental investigation of sill formation and propagation in layered elastic media. Earth Planet. Sci. Lett. 245, 799-813.

Lister, J. R. and R. C. Kerr (1991). Fluid-mechanical models of crack propagation and their application to magma transport in dykes. J. Geophys. Res. 96, 10,049-10,077.

Maclennan, J. and B. Lovell (2002). Control of regional sea level by surface uplift and subsidence caused by magmatic underplating of Earth's crust. Geology 30, 675-678.

Marko, W. T. and A. S. Yoshinobu (2009, this issue). Using restored cross sections to disassemble a magma chamber: Construction of the White Horse pluton, eastern Nevada, USA. Tectonophysics.

McCaffrey, K. J. W. and A. R. Cruden (2002). Dimensional data and growth models for intrusions. In C. Breitkreuz, A. Mock, and N. Petford (Eds.), First International Workshop: Physical Geology of Subvolcanic Systems - Laccoliths, Sills, and Dykes (LASI), Volume 20 of Wissenschaftliche Mitteilungen des Institutes für Geologie der TU Bergakademie Freiberg, pp. 37-39. 
Menand, T. (2008). The mechanics and dynamics of sills in elastic layered media and their implications for the growth of laccoliths. Earth Planet Sci. Lett. 267, 93-99.

Menand, T., K. Daniels, and P. Benghiat (2009). Dyke propagation and sill formation in a compressive tectonic environment. J. Geophys. Res.. sub judice.

Mériaux, C. and J. R. Lister (2002). Calculation of dike trajectories from volcanic centers. J. Geophys. Res. 107 (B4)(2077), doi:10.1029/2001JB000436.

Michaut, C. and C. Jaupart (2006). Ultra-rapid formation of large volumes of evolved magma. Earth Planet. Sci. Lett. 250, 38-52.

Michaut, C. and C. Jaupart (2009, this issue). Two models for the formation of magma reservoirs by small increments. Tectonophysics, 1-16.

Michel, J., L. Baumgartner, B. Putlitz, U. Schaltegger, and M. Ovtcharova (2008). Incremental growth of the Patagonian Torres del Paine laccolith over 90 ky. Geology 36(6), 459-462.

Miller, C. F., D. J. Furbish, B. A. Walker, L. L. Claiborne, G. C. Koteas, H. A. Bleick, and J. S. Miller (2009, this issue). Growth of plutons by incremental emplacement of sheets in crystal-rich host: Evidence from miocene intrusions of the colorado river region, nevada, usa. Tectonophysics, 1-13.

Morgan, S. S., E. Horsman, B. Tikoff, M. de Saint-Blanquat, and G. Habert (2005). Sheet-like emplacement of satellite laccoliths, sills and bysmaliths 
of the Henry Mountains, Southern Utah. In J. Pederson and C. M. Dehler (Eds.), Interior Western United Sates, Volume 6 of Geological Society of America Field Guide. doi:10.1130/2005.fld006(14).

Morgan, S. S., A. Stanik, E. Horsman, B. Tikoff, M. de Saint-Blanquat, and G. Habert (2008). Emplacement of multiple magma sheets and wall rock deformation: Trachyte mesa intrusion, henry mountains, utah. J. Struc. Geol. 30, 491-512.

Mudge, M. R. (1968). Depth control of some concordant intrusions. Geol. Soc. Am. Bull. 79, 315-332.

Parsons, T., N. H. Sleep, and G. A. Thompson (1992). Host rock rheology controls on the emplacement of tabular intrusions: Implications for underplating of extending crust. Tectonics 11, 1348-1356.

Pasquarè, F. and A. Tibaldi (2007). Structure of a sheet-laccolith system revealing the interplay between tectonic and magma stresses at Stardalur Volcano, Iceland. J. Volcanol. Geotherm. Res. 161, 131-150.

Paterson, S. R., V. Memeti, R. Economos, D. Okaya, and R. B. Miller (2009, this issue). The incremental growth of large magma chambers in continental margin arcs: results from field, geochronologic, geochemical and thermal modeling studies. Tectonophysics.

Paterson, S. R., G. S. Pignotta, D. Farris, V. Memeti, R. B. Miller, R. H. Vernon, and J. Žák (2008). Is stoping a volumetrically signifi cant pluton emplacement process?: Discussion. Geol. Soc. Am. Bull. 120, 1075-1079. 
Petford, N., A. R. Cruden, K. J. W. McCaffrey, and J. L. Vigneresse (2000). Granite magma formation, transport and emplacement in the earth's crust. Nature 408, 669-673.

Petraske, A., D. Hodge, and R. Shaw (1978). Mechanics of emplacement of basic intrusions. Tectonophysics 46(1-2), 41-63.

Pinel, V. and C. Jaupart (2004). Magma storage and horizontal dyke injection beneath a volcanic edifice. Earth Planet. Sci. Lett. 221, 245-262.

Pollard, D. D. and G. Holzhausen (1979). On the mechanical interaction between a fluid-filled fracture and the Earth's surface. Tectonophysics 53, $27-57$.

Pollard, D. D. and A. M. Johnson (1973). Mechanics of growth of some laccolithic intrusions in the Henry Mountains, Utah, II. Bending and failure of overburden layers and sills formation. Tectonophysics 18, 311-354.

Quick, J. E., S. Sinigoi, and A. Mayer (1994). Emplacement dynamics of a large mafic intrusion in the lower crust, Ivrea-Verbano Zone, northern Italy. J. Geophys. Res. 99, 21,559-21,573.

Roman, D. C., S. C. Moran, J. A. Power, and K. V. Cashman (2004). Temporal and spatial variation of local stress fields before and after the 1992 eruptions of Crater Peak Vent, Mount Spurr volcano, Alaska. Bull. Seismol. Soc. Am. 94, 2366-2379.

Roman, D. C., J. Neuberg, and R. R. Luckett (2006). Assessing the likelihood of volcanic eruption through analysis of volcanotectonic earthquake faultplane solutions. Earth Planet. Sci. Lett. 248, 244-252. 
Rutter, E. H., K. H. Brodie, and P. J. Evans (1993). Structural geometry, lower crustal magmatic underplating and lithospheric stretching in the ivrea-verbano zone, northern italy. Journal of Structural Geology 15, 647662.

Taisne, B. and C. Jaupart (2009). Dike propagation through layered rocks. Journal of Geophysical Research 114(B9), B09203.

Thomson, K. (2007). Determining magma flow in sills, dykes and laccoliths and their implications for sill emplacement mechanisms. Bull. Volcanol. 70, 183-201.

Thomson, K. and D. Hutton (2004). Geometry and growth of sill complexes: insights using 3d seismic from the North Rockall Trough. Bull. Volcanol. 66, 364-375.

Tibaldi, A. and F. A. Pasquarè (2008). A new mode of inner volcano growth: The "flower intrusive structure". Earth Planet. Sci. Lett. 271, 202-208.

Vigneresse, J. L. (2009, this issue). Incremental granite pluton building and elastic near-stress field reorientaion. Tectonophysics.

Vigneresse, J. L. and J. L. Bouchez (1997). Successive granitic magma batches during pluton emplacement: the case of cabeza de araya (spain). J. Petrol. 38, 1767-1776.

Westerman, D., A. Dini, F. Innocenti, and S. Rocchi (2004). Rise and fall of a nested christmas-tree laccolith complex, elba island, italy. Physical Geology of High-level Magmatic Systems: Geological Society, London, Special Publication 234, 195-213. 
Wiebe, R. A. and W. J. Collins (1998). Depositional features and stratigraphic sections in granitic plutons: implications for the emplacement and crystallization of granitic magma. J. Struc. Geol. 20, 1273-1289.

Yoshinobu, A. S. and C. G. Barnes (2008). Is stoping a volumetrically signifi cant pluton emplacement process?: Discussion. Geol. Soc. Am. Bull. 120, 1080-1081. 


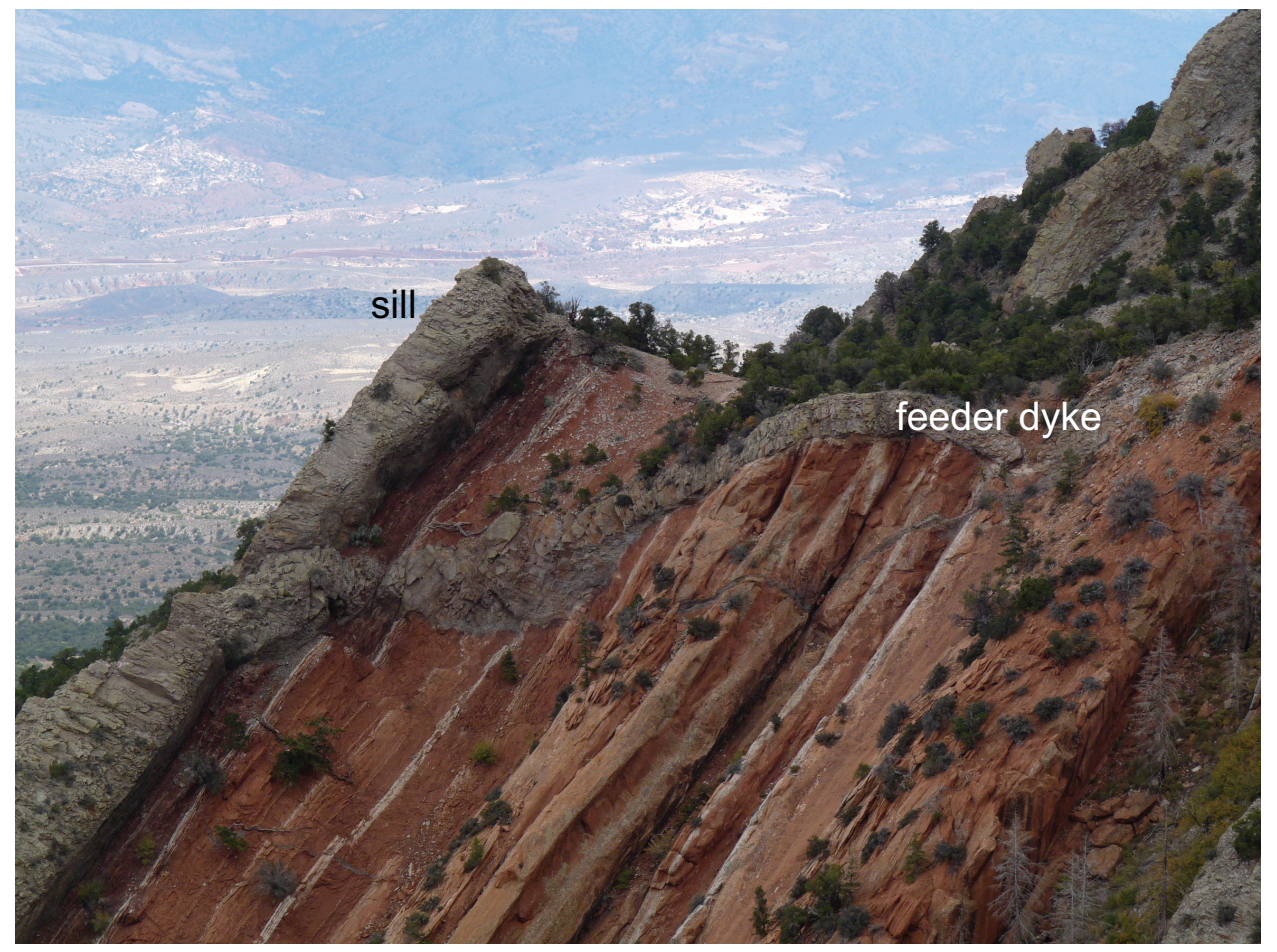

Figure 1: Photograph of a rotated sill with its feeder dike on the south side of Gold Creek, east Mount Hillers, Henry Mountains, Utah, USA. The view is from the east. The sill, its feeder and the intruded sandstone have all been rotated almost $90^{\circ}$ by the later formation of Mount Hillers' intrusive centre (situated further north, to the right of the photograph). Photo courtesy of Michel de Saint-Blanquat. 


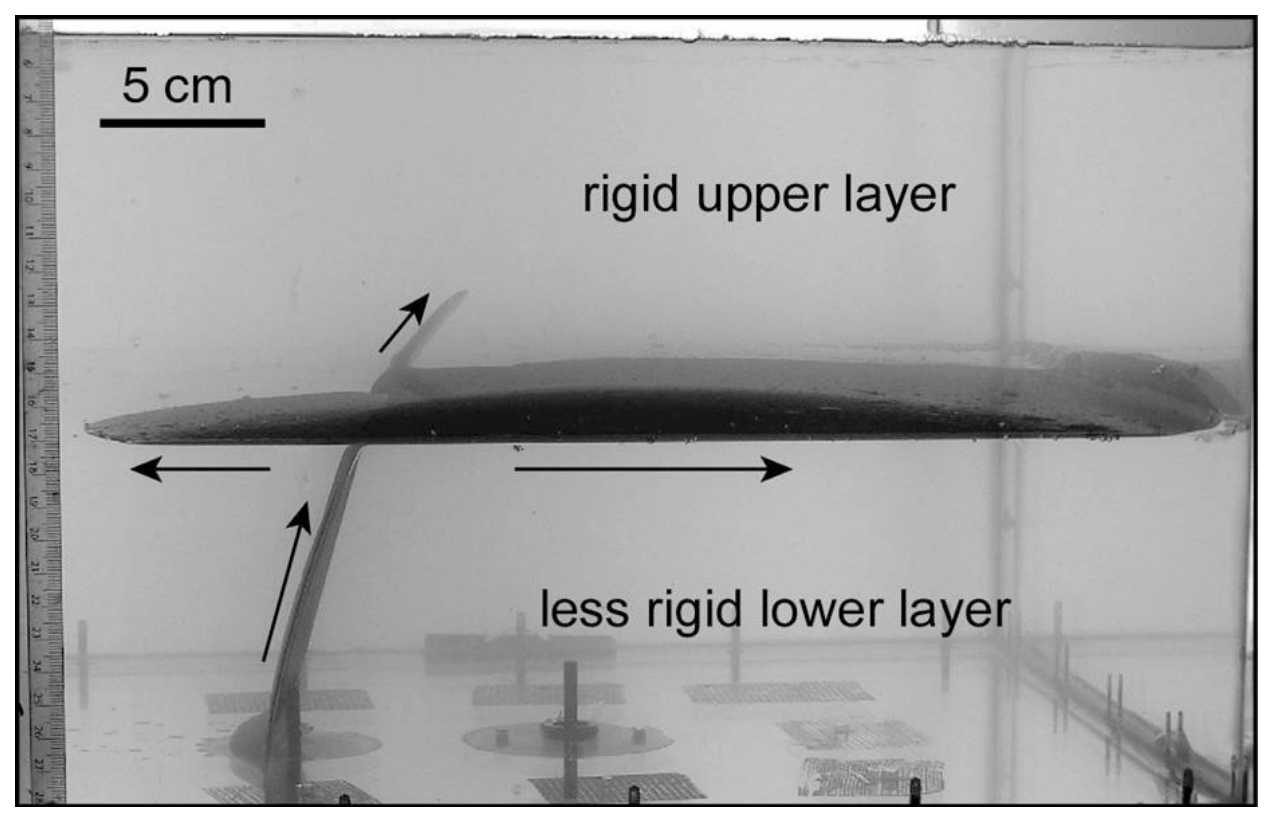

Figure 2: A photograph of a rigidity-controlled sill formation (Kavanagh et al., 2006). The rigidity modulus of the upper layer was $10 \%$ larger than that of the lower layer. The feeder dyke propagated from the injection point toward the interface, reached it and then intruded the interface as a sill in both opposite directions from the point where the dyke intersected the interface. Note the protruding dykelet that extended beyond the interface and into the more rigid upper layer; this dykelet was short-lived and stalled whilst the sill continued propagating. The arrows indicate flow directions. 

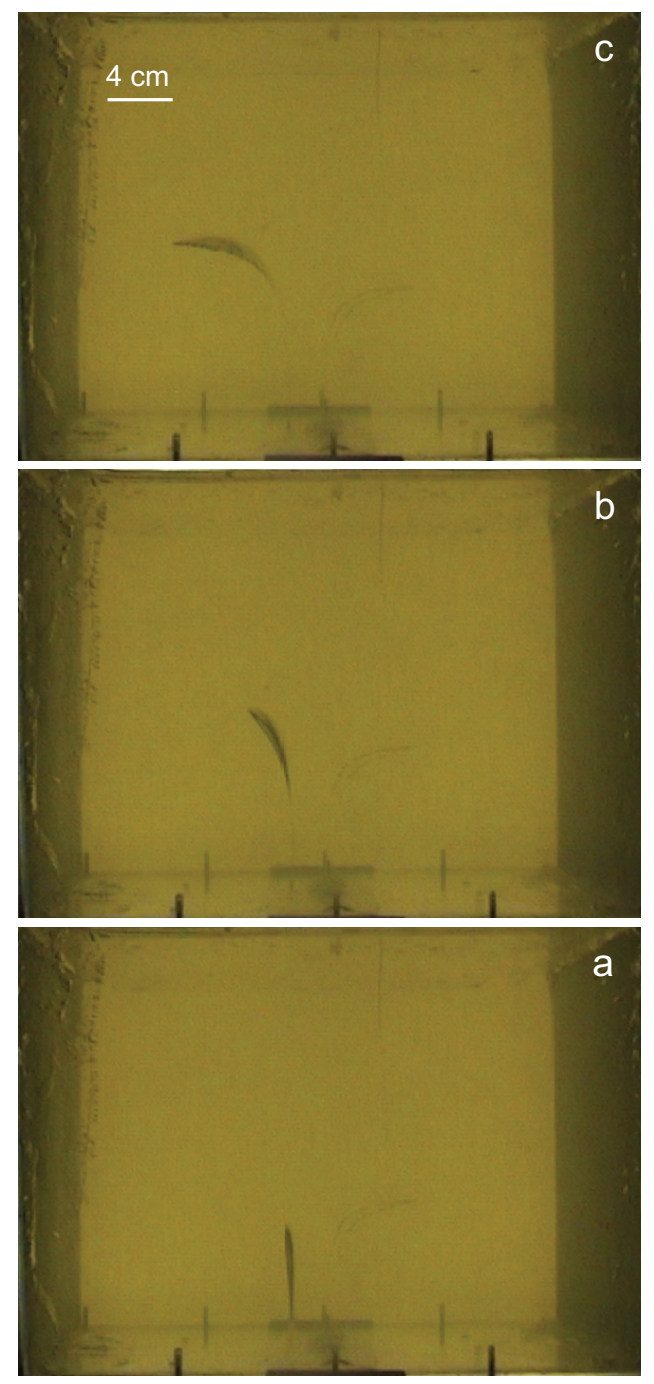

Figure 3: A series of photographs of a stress-controlled sill formation (Menand et al., 2009). The ratio of initial crack buoyancy to horizontal compressive stress was 2.1. (a) The injection of air in the gelatine solid created a crack that was initially driven vertically by the air buoyancy. (b) The gelatine solid was compressed laterally, and so the crack experienced an additional horizontal compressive stress to which it reacted by changing its direction of propagation. (c) Ultimately, the crack rotated by $90^{\circ}$ and formed a sill before coming to a stop. 


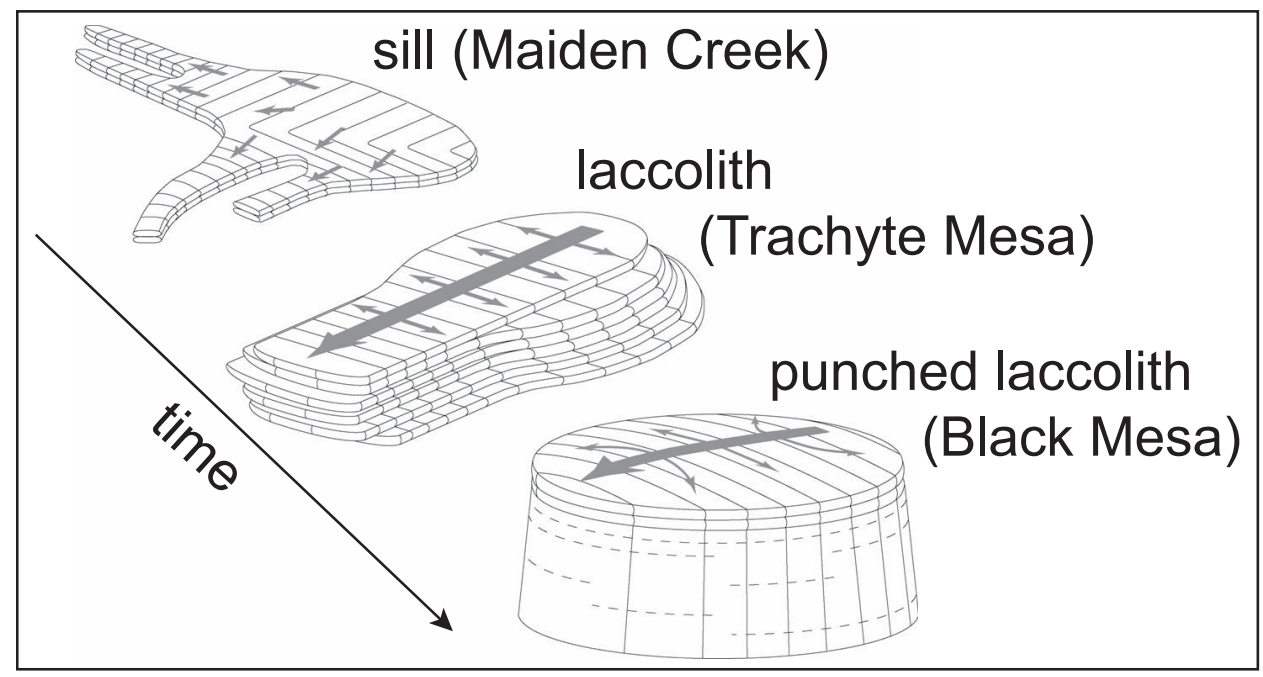

Figure 4: Illustration of the evolution through time of an idealized upper crustal pluton, based on field observations in the Henry Mountains, Utah by Morgan et al. (2005) and Horsman et al. (2009). These intrusions would initiate as sills, then evolve into laccoliths, before becoming punched-laccoliths. 